\title{
PENDAPATAN PETANI DAN KEANEKARAGAMAN TANAMAN PADA BERBAGAI POLA USAHA WANATANI DI SUB DAS MINRALENG HULU KABUPATEN MAROS
}

\author{
Farmer Income and Plant Diversity on Several Agroforestry Pattern in Upperstream Minraleng Sub \\ Watershed, Maros Regency \\ Muh. Dassir
}

\begin{abstract}
The plant diversity using shanon index and the farmer income level were investigated in this study. This information is very important to contribute some improvement of agroforestry pattern related to the farmer welfare and the ecological productivity in upperstream Minraleng Sub Watershed. Results show that the diversity index of mix public forest was higher than the other patterns, eventhough it has a lower contribution compared to paddyfield. Paddyfield and unirigated-land have a higher contribution to farmer income, but they have lower diversity indexes. In contrast, candlenut monoculture and mix garden have higher diversity indexes and lower contribution to farmer income. A plant diversification under candlenut stands and an economical plant intensification on mix garden were needed to increase the farmer income and the diversity of economic plants.
\end{abstract}

Key words: Diversity index, farmer income, agroforestry, Minraleng Sub Watershed

\section{PENDAHULUAN}

Sistem-sistem wanatani di Asia Tenggara telah berkembang selama berabad-abad menjadi berbagai sistem yang rumit seperti yang dapat diamati pada sekarang ini. Pada saat ini pun, sesuai dengan perubahan keadaan, para petani masih berlanjut bereksperimen dan memperbaiki sistem-sistem itu (Ginting, 1997). Sedangkan menurut Foresta (2000), wanatani lahir dari praktek tradisional pengelolaan hutan dan dikembangkan terus menerus oleh masyarakat setempat sebagai bagian dari sistem pertanian setempat. Keberhasilan wanatani merupakan hasil interaksi positif antara dinamika biologi, pengetahuan, teknik, dan sistem kelembagaan masyarakat setempat. Hasil penelitian Ruf dan Lancon (2005) menggambarkan perkembangan wanatani di Indonesia disebabkan oleh faktor pertambahan penduduk menyebabkan keterbatasan lahan, contohnya wanatani di Nusa Tenggara Timur dari peternakan dengan padang penggembalaan (1960) ke kombinasi kehutanan-peternakan (1970) dan tahun 1980 berkembang menjadi kehutanan-pertanian-peternakan dengan produk makanan ternak, tanaman semusim, pohon buah dan penghasil kayu. Hasil pengamatan lainnya dari Reijntjes, et al (1992) di Kupang, yaitu dari wanatani berladang berpindah ke wanatani agrosilvofastural (pertanian-kehutanan-peternakan) dengan tetap melakukan berladang berpindah dikarenakan pertambahan populasi penduduk lebih lambat dan lahan masih tersedia.

Hulu Sub DAS minraleng merupakan Hulu DAS Walanae yang terdapat di Kecamatan Cenrana, Kecamatan Camba, dan Kecamatan Mallawa Kabupaten Maros. Luas lahan Sub DAS Minraleng yaitu 69.395 ha, di antaranya 18.446 ha merupakan lahan kritis, sehingga Sub DAS ini termasuk wilayah prioritas penanganan DAS (Millang, 2003). Berdasarkan hasil interpretasi peta citra satelit skala 1:250.000 tahun 2002, penutupan lahan yang terdapat pada Sub DAS Minraleng Hulu, sangat bervariasi dari padang rumput (14.690 ha), sawah (19.699), pertanian lahan kering campur semak (10.703) dan areal berhutan (11. $531 \mathrm{ha}$ ) berupa hutan alam dan hutan tanaman (hutan rakyat dan hutan pinus hasil reboisasi oleh pemerintah). Salah satu permasalahan pada Sub DAS Minraleng Hulu, yaitu penutupan lahan dengan berbagai pola penggunaan lahan yang kurang bagus berdampak pada terjadinya banjir pada musim hujan dan kekeringan pada musim kemarau pada desa-desa hilir yang terletak di sekitar Danau Tempe, sehingga pertanian daerah hilir mengalami 
kekurangan air irigasi. Kondisi tersebut perlu ada upaya pemanfaatan lahan dengan tetap menjaga kelestarian produktifitas lahan, melalui usaha intensifikasi dan diversivikasi usaha wanatani.

Pengembangan pemanfaatan lahan wanatani dapat dilakukan dengan menganalisis pendapatan para petani wanatani, seperti penggunaan rata-rata masukan per ha pada berbagai pola wanatani, baik dalam bentuk pupuk, varietas-varietas unggul maupun tenaga kerja yang diperlukan untuk peningkatan produksi wanatani. Kondisi tersebut perlu pemahaman menyangkut: (a) Struktur hubungan antara pola wanatani dan tingkat keanekaragaman jenis tanaman wanatani yang diusahakan, (b) Besarnya pendapatan kotor dan pendapatan bersih petani pada berbagai keanekaragaman jenis tanaman wanatani yang diusahakan. Informasi keanekaragaman jenis dan tingkat pendapatan petani pada berbagai pola wanatani yang diusahakan dapat menuntun berbagai upaya perbaikan pola wanatani dan upaya yang mungkin dapat dilakukan dalam memperbaiki kesejahteraan masyarakat tersebut (Jamal, 2000), dan untuk meningkatkan produktifitas ekologis Sub DAS Minraleng Hulu.

Penelitian ini bertujuan untuk: (1) Mengetahui keanekaragaman jenis berbagai pola wanatani rakyat, (2) Mengetahui pendapatan petani pada berbagai pola wanatani rakyat, dan (3) Bahan masukan dalam merumuskan perbaikan pola wanatani yang dapat meningkatkan pendapatan petani dan perbaikan kualitas/ekologi lahan.

\section{BAHAN DAN METODE}

\section{Waktu dan Tempat Penelitian}

Penelitian ini dilaksanakan selama enam bulan, mulai Agustus 2006 sampai Januari 2007 pada Sub DAS Minraleng Hulu Kabupaten Maros.

\section{Populasi dan Sampel Penelitian}

Populasi pada penelitian ini, yaitu seluruh petani yang terdapat pada Sub DAS Minraleng Hulu yang melakukan aktivitas usaha wanatani, meliputi Kecamatan Cenrana, Kecamatan Camba dan Kecamatan Mallawa Kabupaten Maros. Penentuan desa sampel penelitian dilakukan mengunakan metode cluster sampling, yaitu dari masing-masing kecamatan dipilih satu desa yang dapat mewakili keragaman dinamika usaha wanatani.

Wilayah desa yang terpilih didasarkan pada pertimbangan jumlah penduduk, teknologi yang digunakan, luas desa, letak desa, dan agroekosistem yang terdapat dan berkembang. Berdasarkan pertimbangan tersebut dipilih tiga desa, yaitu Desa Batu Pute Kecamatan Mallawa yang mewakili desa-desa dengan usaha tani, yaitu: (1) kebun kemiri dan jati yang lebih dominan, (2) pembangunan dan pengembangan wanatani kemiri dan jati mengarah ke agrobisnis tanaman tahunan, (3) dan luas lahan penduduk. Desa Timpuseng yang mewakili kecamatan Camba dengan karakteristik: (1) usaha wanatani tanaman semusim lebih dominan, (2) pembangunan dan pengembangan usaha wanatani mengarah ke usahatani persawahan, (3) etnis penduduk desa tersebut merupakan campuran etnis Bugis dan Makassar, (4) terletak di sepanjang jalan provinsi hingga ke pegunungan, dan (5) lahan pertanian penduduk sempit. Desa Limampoccoe yang mewakili Kecamatan Cenrana dengan karakteristik: (1) pola pertanian pangan lahan kering pada kawasan hutan lebih dominan, (2) pembangunan dan pengembangan usaha wanatani pada kawasan hutan pinus mengarah ke tegalan dan lahan perkebunan (coklat, kopi), (4) lahan pertanian penduduk sempit dan kawasan hutan pinus masih luas.

Penentuan responden pada masing-masing desa sampel dilakukan secara pengelompokan acak berlapis (cluster stratified random sampling). Berdasarkan kriteria tersebut, maka jumlah responden yang dipilih pada setiap desa ditentukan berdasarkan hasil perhitungan menggunakan rumus Cohran (1977) dengan jumlah sampel rumah tangga pada setiap desa sampel penelitian, seperti pada Tabel 1.

Table 1. Population and samples Measurement

\begin{tabular}{|l|l|c|c|}
\hline Kecamatan & Desa & $\begin{array}{c}\text { Populasi } \\
\text { (KK) }\end{array}$ & $\begin{array}{c}\text { Sampel } \\
\text { Penelitian } \\
\text { (KK) }\end{array}$ \\
\hline Cenrana & Limampoccoe & 549 & 91 \\
\hline Camba & Timpuseng & 421 & 81 \\
\hline Mallawa & Batu pute & 242 & 40 \\
\hline \multicolumn{3}{|c|}{ Total sampel penelitian } & 212 \\
\hline
\end{tabular}


Table 2. Technical of Data Collection, Data Type, and Equipments

\begin{tabular}{llll}
\hline \begin{tabular}{c} 
Teknik \\
\multicolumn{1}{c}{$\begin{array}{c}\text { Pengumpulan } \\
\text { data }\end{array}$}
\end{tabular} & \multicolumn{1}{c}{ Jenis data yang dikumpulkan } & $\begin{array}{c}\text { Responden yang } \\
\text { diwawancarai }\end{array}$ & \multicolumn{1}{c}{$\begin{array}{c}\text { Peralatan yang } \\
\text { digunakan }\end{array}$} \\
\hline Wawancara & $\begin{array}{l}\text { Jenis tanaman yang dibudidayakan, peralatan } \\
\text { wanatani, pengolahan hasil, pemasaran hasil, dan }\end{array}$ & $\begin{array}{l}\text { petani wanatani } \\
\text { berbagai strata }\end{array}$ & \\
& $\begin{array}{l}\text { peralatan transportasi, serta biaya dan pendapatan } \\
\text { petani. }\end{array}$ & $\begin{array}{l}\text { penguasaan } \\
\text { lahan }\end{array}$ & Questionaire \\
Pengamatan & - Jenis tanaman yang dibudidayakan & ---- & Plot pengamatan \\
lapang & - Pola tanam & & \\
\hline
\end{tabular}

\section{Teknik Pengumpulan Data dan Jenis Data}

Gambaran secara lengkap teknik pengumpulan data dan jenis data yang dikumpulkan pada penelitian ini dapat dilihat pada Tabel 2.

\section{Analisis Data}

Berdasarkan hasil pengamatan lapangan dan wawancara, dilakukan analisis kuantitatif, meliputi:

1. Analisis pendapatan dilakukan untuk melihat pendapatan petani pada berbagai pola wanatani dengan rumus:

$$
P=B P n-B T
$$

di mana:

$P=$ Pendapatan petani (Rp/thn)

$B=$ Harga jual berbagai hasil wanatani petani (Rp/kg)

$P n=$ Jumlah produksi berbagai hasil wanatani petani $(\mathrm{kg} / \mathrm{thn})$

$\mathrm{BT}=$ Biaya total wanatani rakyat

2. Menghitung indeks keanekaragaman flora $(H)$ menggunakan indeks Shanon pada berbagai pola wanatani, dengan rumus:

$$
\begin{aligned}
& H=-\sum\left\{\left(\frac{n i}{n}\right) \ln \left(\frac{n i}{n}\right)\right\} \\
& \text { dimana }: \mathrm{H}=\text { indeks keanekaragaman } \\
& \mathrm{ni}=\text { jumlah individu perjenis } \\
& \mathrm{n}=\text { jumlah total individu }
\end{aligned}
$$

\section{HASIL DAN PEMBAHASAN}

\section{Pola Wanatani}

Berdasarkan hasil pengamatan lapang pada berbagai pola wanatani di Sub DAS Minraleng Hulu Kabupaten Maros, terdapat beberapa pola wana- tani yang umumnya dikembangkan masyarakat, meliputi:

\section{Pola ladang}

Pola ladang yang terdapat pada Sub DAS Minraleng Hulu, yaitu berladang berpindah-pindah dengan lama perpindahan dari suatu lahan ke lahan lainnya sekitar 2-3 tahun, kemudian pindah ke lahan lain dan dilakukan secara berkelompok 5-7 orang per kelompok pada suatu hamparan lahan. Pola tanaman yang diterapkan, tahun pertama sampai tahun ke tiga, yaitu jagung+ kacang-kacangan. Peralatan yang digunakan masih menggunakan parang, cangkul, kapak, dan linggis. Pola perladangan ini dijumpai pada Desa Limapoccoe. Pola ladang ke dua adalah berladang secara bero lahan yang dijumpai pada ketiga desa lokasi penelitian dengan masa bera empat tahun, kemudian kembali diolah. Pola ini telah menggunakan peralatan pupuk pestisida, terasering dan bahkan ada yang telah menggunakan traktor dalam pengolahan lahan.

Penduduk melakukan sistem berladang tidak ke sistem berkebun menetap dikarenakan faktor iklim mikro lahan yang tidak cocok (sangat dingin) dan faktor tanah yang kurang subur (setelah mencoba berbagai jenis tanaman perkebunan dan tanaman pekarangan) serta tanaman komersil lainnya seperti lombok, mangga, rambutan, durian, mangga dan tomat buah. Di samping faktor luasan lahan usaha wanatani yang datar pada satu hamparan sulit ditemukan pada daerah pegunungan seperti demikian.

\section{Pola wanatani kemiri monokultur}

Pola ini didominasi pohon kemiri dengan jarak tanam yang bervariasi dari $5 \times 5 \mathrm{~m}, 7 \times 7 \mathrm{~m}$, sampai dengan $8 \times 10 \mathrm{~m}$ dengan pola yang tidak beraturan. Umumnya umur kemiri pada pola ini berumur tua 30 tahun ke atas karena regenerasi kemiri jarang dilakukan. Kebun atau lahan kemiri 
dengan pola seperti ini biasanya dimiliki oleh petani yang memiliki lahan kemiri yang cukup luas.

\section{Pola wanatani kemiri campuran}

Pola ini merupakan pengembangan dari pola budidaya kemiri monokultur yang mengkombinasikan tanaman kemiri dengan jenis tanaman tahunan lainnya. Jenis tanaman yang dikembangkan pada pola ini lebih bervariasi meliputi jati, kemiri, kelapa, nangka, coklat sebagai tanaman dominan. Pola ini biasanya terdapat pada areal kemiri yang dekat atau berada di sekitar pemukiman.

\section{Wanatani kebun campuran dominan coklat}

Wanatani kebun campuran dominan coklat yang banyak terdapat pada lokasi penelitian adalah pada penduduk di Desa Batupute yang pada awal pembukaannya merupakan lahan alang-alang atau padang rumput. Tahun pertama sampai tahun ketiga areal tersebut diladangi dan telah dipersiapkan tanaman gamal sejak tahun pertama sebagai bakal pohon pelindung. Untuk mengatasi pembatas iklim yang curah hujannya hanya sekitar 3-4 bulan hujan (iklim D klasifikasi Schmidt Ferguson), maka memasuki tahun ke tiga dari proses perladangan maka ditanami dengan pisang. Akhir tahun ke empat baru ditanami coklat dan tahun ketujuh atau kedelapan dari pengelolaan lahan tersebut (umur coklat telah 3-4 tahun) tanaman coklat tersebut telah menghasilkan buah. Wanatani kebun coklat banyak berkembang disebabkan lahan persawahan sebagian besar merupakan sawah tadah hujan dengan iklim wilayah adalah $C$ sampai $D$, sedangkan luas lahan milik penduduk dengan penutupan alang-alang ataupun kemiri dan atau jati secara campuran dan monokultur rata-rata masih luas ( $>1,5$ ha per $\mathrm{KK}$ ). Berkembangnya wanatani coklat tersebut didukung oleh pengalaman pada kecamatan terdekat yang terdapat pada kabupaten Bone, yaitu Kecamatan Lappariaja.

\section{Wanatani pekarangan}

Wanatani pekarangan yang terdapat pada Desa Limampoccoe, adalah agroforestry dominan jambu mete dengan tanaman bawah adalah kopi dan pohon pagar berupa mahoni, dan atau jati putih sebagai ciri pembatas antara lahan pekarangan petani dengan petani lainnya, sedang pada Desa Timpuseng wanatani pekarangan yang berkembang adalah wanatani campuran pisang, kopi, coklat atau dominan aren dengan campuran bambu dan pinang. Wanatani pekarangan pada Desa Batupute adalah wanatani dominan coklat dengan campuran pisang.

\section{Wanatani jati monokultur}

Wanatani jati monokultur sebagian besar terdapat di Desa Batupute Kecamatan Mallawa yang dimiliki oleh tuan tanah yang mempunyai stratifikasi sosial kalangan bangsawan. Wanatani jati monokultur tersebut masih bertahan sampai sekarang dalam skala luas, dikarenakan tuan tanah tersebut struktur pendapatannya sebagian besar berasal dari persawahan dan hasil ternak sapi secara penggembalaan liar dengan rata-rata kepemilikan ternak di atas 15 ekor/KK. Wanatani jati monokultur oleh tuan tanah dijadikan asset untuk jangka panjang yang kadang-kadang dijual perpohon (5-10 pohon) untuk mendapat dana tunai jika sewaktu-waktu membutuhkan dana. Lahan jati monokultur tersebut juga merupakan lahan untuk mempertahankan sistem patron-klien melalui pembagian lahan dengan kliennya melalui sistem pakkoko pada saat konversi tegakan jati menjadi wanatani dominan coklat (coklat + jati) dengan pembagian $1: 1$ dengan rata-rata luas lahan yang dikonversi seluas satu ha yang berarti wanatani coklat campuran yang berkembang nantinya masing-masing dibagi seluas 0,5 ha antara patron dengan kliennya.

Wanatani jati monokultur juga terdapat pada sebagian kecil penduduk strata sosial menengah, di mana wanatani jati monokultur tersebut dipertahankan sebagai jati monokultur, dikarenakan sumber pendapatannya dari persawahan atau karena pegawai negeri, atau karena tegakan jati monokultur tersebut sesuai pengalamannya tidak sesuai untuk dikonversi ke wanatani lain karena kondisi lahan tersebut kurang subur (berbatu).

\section{Wanatani jati campuran}

Wanatani jati campuran sebagian besar terdapat pada Desa Batupute Kecamatan Mallawa. Wanatani jati campuran tersebut merupakan proses dari konversi jati monokultur oleh pemilik hutan jati yang mempunyai keahlian meremajakan jati menjadi wanatani jati campuran secara terubusan atau konversi jati oleh pakkoko dengan sistem bagi hasil luas lahan yang dikonversi dari tuan tanah pemilik jati monokultur. 


\section{Wanatani hutan rakyat campuran}

Hutan rakyat ini berbeda dengan hutan kemiri dan jati rakyat yang ditujukan untuk produksi buah dan kayu. Hutan rakyat campuran ini kebanyakan terdapat di Desa Limampoccoe yang ditujukan untuk produksi kayu (papan dan balokbalok) di samping sebagai penanda kepemilikan lahan penduduk. Jenis tanaman pengisi hutan rakyat campuran tersebut merupakan jenis-jenis pohon daun lebar penghasil kayu yang diperkenalkan oleh departemen kehutanan melalui kegiatan reboisasi dan penghijauan pada wilayah tersebut, seperti gmelina, mahoni, puspa dan jenis lainnya.

\section{Keanekaragaman Tanaman}

\section{Desa Limampoccoe}

Indeks keanekaragaman jenis tumbuhan yang diamati pada penelitian ini, yaitu jumlah jenis dan banyaknya tumbuhan per jenis pada berbagai ruang tumbuh yang dibagi dalam empat kategori ruang tumbuh (strata $A, B, C$, dan strata $D$ ). Strata $A$ untuk jenis tumbuhan yang penutupan tajuknya paling atas, disusul strata $B$ yang penutupan tajuknya di bawah strata $B$, strata $C$ penutupan tajuknya di bawah strata tajuk $C$, dan strata $D$ yang merupakan vegetasi pada lantai hutan di bawah strata tajuk C. Hasil perhitungan indeks keanekaragaman jenis tumbuhan pada berbagai pola wanatani di Desa Limampoccoe memperlihatkan variasi nilai indeks keanekaragaman pada berbagai strata (Tabel 3).

Table 3. Average of Plant Diversity Index on Each Agroforestry Pattern at Limampoccoe Village

\begin{tabular}{lcccc}
\hline \multirow{2}{*}{$\begin{array}{c}\text { Agroforestry } \\
\text { pattern }\end{array}$} & \multicolumn{4}{c}{ Plant diversity index based on } \\
\cline { 2 - 5 } & Strata & Strata & Strata & Strata \\
& A & B & C & D \\
\hline Ladang & 1,541 & 0,580 & 0,693 & 1,683 \\
Tegakan kemiri & 0,643 & 0,562 & 0,598 & 1,089 \\
Hutan & & & & \\
Campuran & 1,694 & 1,562 & 1,162 & 0,678 \\
\hline
\end{tabular}

Tabel 3 di atas memperlihatkan indeks keanekaragaman pada wanatani ladang tertinggi terdapat pada Strata $D(1,683)$, disusul pada Strata A $(1,541)$, Strata C $(0,693)$ dan strata B $(0,287)$. Hal ini menunjukkan pemanfaatan ruang tumbuh permukaan tanah (lantai hutan) sangat intensif dimanfaatkan dan dikelola untuk penanaman tanaman semusim, sedang untuk strata $A$, strata $B$ dan $C$ disisakan beberapa jenis komersil sebagai penanda kepemilikan lahan saat akan ditinggalkan seperti kemiri dan atau jati apabila lahan tersebut tidak akan dikonversi menjadi kebun campuran. Wanatani ladang mempunyai indeks keanekaragaman tertinggi pada strata $D$, dikarenakan jenis tanaman semusim yang banyak ditanam, yaitu kacang tanah, jagung, jahe. Kacang tanah dan atau jagung ditanam pada awal dan akhir musim hujan yang dilakukan dua kali setahun, sedang jahe dilakukan setahun sekali. Strata A menempati urutan kedua, hal ini menunjukkan bahwa pemanfaatan ruang lantai hutan sangat intensif, sehingga resiko terjadinya erosi sangat tinggi, sedang tingkat pohon hanya jenis-jenis seperti jati, jati putih dan puspa yang dipangkas untuk membuka ruang tumbuh bagi tanaman semusim dibawahnya, kondisi ini kurang berfungsi terhadap perlindungan dari erosi permukaan tanah.

Indeks keanekaragaman jenis pada tegakan kemiri menunjukkan strata $D$ mempunyai keanekaragaman yang tertinggi sebesar 1,089 , disusul strata A $(0,643)$, strata C $(0,598)$, dan strata B $(0,562)$. Hal ini mengindikasikan bahwa pengelolaan kemiri cenderung tidak ada, hanya dikelola pada saat pemungutan kemiri. Sehingga pemanfaatan ruang tumbuh pada berbagai ruang tumbuh sama sekali tidak ada.

Pada usaha wanatani hutan rakyat campuran, indeks keanekaragaman jenisnya antara strata $A(1,694)$, strata $B(1,562)$ dan strata C $(1,162)$ cenderung hampir sama, ini menunjukkan pengelolaan ruang tumbuh pada pelbagai strata ruang tumbuh dimanfaatkan secara optimal melalui pemilihan jenis tanaman yang ditanam, pengaturan jarak tanam, dan pengaturan assosiasi antar jenis tumbuhan untuk tujuan komersil. Sedang strata D $(0,678)$ lebih rendah dikarenakan $80-90 \%$ lantai hutan/kebun campuran tertutupi strata lapisan tajuk di atasnya, disamping adanya aktivitas pengelolaan berupa pembersihan tumbuhan bawah dan seleksi tanaman yang tumbuh pada lantai hutan oleh petani responden pemilik hutan rakyat. Strata A dan strata B memiliki indeks keanekaragaman lebih tinggi dibanding strata $C$ dan $D$, hal ini menunjukkan pemanfaatan ruang tumbuh pada strata atas lebih dominan untuk tujuan penghasil kayu dan buah, sedang strata $C$ lebih intensif untuk tujuan pengusahaan komoditas perkebunan seperti kopi, 
pisang dan coklat. Strata D nilai indeks keragamannya yang terendah, dikarenakan petani melakukan pembersihan tumbuhan bawah dan seleksi tumbuhan pada lantai hutan yang dibiarkan untuk tumbuh, hal ini menunjukkan intensitas pengelolaan pada hutan rakyat campuran lebih tinggi dibanding pada tegakan kemiri.

\section{Desa Batupute}

Hasil perhitungan indeks keanekaragaman berbagai jenis pola wanatani di Desa Batupute menunjukkan usaha wanatani kemiri monokultur mempunyai indeks keanekaragaman yang tertinggi dibanding wanatani lainnya yang cenderung seperti hutan alam (Tabel 4), yaitu mengikuti kurva "J" terbalik, disusul wanatani kebun campuran, wanatani jati monokultur, wanatani pekarangan dan terendah indeks keanekaragamannya pada wanatani ladang.

Table 4. Average of Plant Diversity Index on Each Agroforestry Pattern at Batupute Village

\begin{tabular}{lcccc}
\hline \multirow{2}{*}{$\begin{array}{l}\text { Agroforestry } \\
\text { pattern }\end{array}$} & \multicolumn{4}{c}{ Plant diversity index based on } \\
\cline { 2 - 5 } & Strata & Strata stratification & Strata & Strata \\
& $\mathrm{A}$ & $\mathrm{B}$ & $\mathrm{C}$ & $\mathrm{D}$ \\
\hline Hutan kemiri & 1,51 & 1,33 & 2,40 & 2,29 \\
Pekarangan & 1,0 & - & 0,12 & 0,57 \\
Kebun & 1,33 & 0,197 & 0,05 & 1,54 \\
campuran & & & & \\
ladang & 0.66 & - & 0.29 & 1.11 \\
Hutan jati & 0.24 & 0.30 & 1.7 & 1.12 \\
\hline
\end{tabular}

Indeks keanekaragaman jenis pada setiap tingkatan struktur tegakan pada wanatani kemiri monokultur menunjukkan strata $D$ mempunyai keanekaragaman yang tertinggi, disusul strata $\mathrm{C}$, $B$, dan strata $A$. Hal ini mengindikasikan bahwa pengelolaan kemiri cenderung tidak ada, hanya dikelola pada saat pemungutan kemiri, sehingga pemanfaatan ruang tumbuh pada berbagai ruang tumbuh sama sekali tidak ada.

Pada wanatani pekarangan dominan coklat menunjukkan indeks keanekaragaman jenis tertinggi terdapat pada strata $C$, disusul strata $B, A$, dan strata $D$. Hal ini mengindikasikan bahwa pemanfaatan dan pengelolaan ruang tumbuh di bawah strata $A$ sangat intensif, sedang pada ruang tumbuh lantai hutan rendah keanekaragamannya, dikarenakan penutupan tajuk coklat dan serasah daunnya menimbulkan efek alelopati yang mematikan vegetasi pada lantai hutan.
Pada usaha wanatani kebun campuran, indeks keanekaragaman jenisnya antara strata $A$, $B$, dan strata $C$ cenderung hampir sama, ini menunjukkan pengelolaan ruang tumbuh pada perbagai strata ruang tumbuh dimanfaatkan secara optimal melalui pengaturan jarak tanam, dan assosiasi antar jenis tumbuhan untuk tujuan komersil. Sedang strata D lebih rendah dikarenakan $80-90 \%$ lantai hutan/kebun campuran tertutupi strata lapisan tajuk di atasnya.

Pada wanatani ladang, maka indeks keanekaragaman tertinggi terdapat pada strata D, disusul strata A. Hal ini menunjukkan pemanfaatan ruang tumbuh permukaan tanah (lantai hutan) sangat intensif dimanfaatkan dan dikelola untuk penanaman tanaman semusim, sedang untuk strata A disisakan jenis komersil penanda kepemilikan lahan saat akan ditinggalkan seperti kemiri dan atau jati apabila lahan tersebut tidak akan dikonversi menjadi kebun campuran.

\section{Desa Timpuseng}

Hasil perhitungan indeks keanekaragaman tanaman pada berbagai wanatani di Desa Timpuseng menunjukkan hutan kemiri dan kebun campuran mempunyai tingkat keanekaragaman yang tertinggi pada berbagai tingkatan strata dibanding wanatani ladang dan pekarangan. Keanekaragaman tersebut terjadi dipengaruhi oleh lebih intensifnya pengelolaan wanatani ladang dan pekarangan untuk tujuan tambahan pangan subsistensi petani, sedang pada hutan kemiri dan kebun campuran cenderung tidak ada pengelolaan, dikarenakan komoditas yang dihasilkan sama sekali tidak ada sejak dua tahun terakhir, dan lebih fokusnya perhatian petani pada budidaya di lahan persawahan dan ladang. Gambaran indeks keanekaragan jenis berbagai pola wanatani di Desa Timpuseng disajikan pada Tabel 5.

Table 5. Average of Plant Diversity Index on Each Agroforestry Pattern at Timpusseng Village

\begin{tabular}{lcccc}
\hline \multirow{2}{*}{$\begin{array}{c}\text { Agroforestry } \\
\text { pattern }\end{array}$} & \multicolumn{4}{c}{ Plant diversity index based on canopy } \\
\cline { 2 - 5 } & Stratification \\
\hline Hutan kemiri & A & Strata & Strata & Strata \\
Ladang & -001 & 1,468 & C & D \\
\hline Kebun & - & - & 0,611 & 1,512 \\
Campuran & 0,7902 & 0,325 & 0,778 & 1,140 \\
Pekarangan & 1,304 & 0,711 & 0,841 & 1,1396 \\
\hline
\end{tabular}


Nilai indeks keanekaragaman jenis tumbuhan pada ketiga lokasi penelitian menunjukkan bahwa komoditas yang diusahakan pada lahan sawah untuk tujuan subsistensi, komersil, dan kapitalis bercirikan pola tanam dengan keanekaragaman tanaman yang rendah antar ruang dan antar waktu. Hal ini linier pada wanatani pekarangan dominan coklat. Namun demikian pada kebun campuran, ladang bero, ladang berpindah, hutan kemiri monokultur, hutan rakyat dan hutan jati monokultur mempunyai keanekaragaman yang lebih tinggi dibanding pada lahan pertanian, berbanding terbalik dengan lahan sawah dan wanatani pekarangan dominan coklat tersebut.

\section{Pendapatan Wanatani}

\section{Biaya dan pendapatan wanatani di Desa Limampoccoe}

Hasil analisis biaya dan pendapatan petani responden pada berbagai pola usaha wanatani menunjukkan tingginya curahan tenaga kerja pada pembuatan gula aren dan ladang berpindah dibanding wanatani/usahatani lainnya. Tingginya curahan tenaga kerja tersebut menyebabkan penerimaan bersih petani menjadi negatif apabila faktor tenaga kerja dalam keluarga diperhitungkan sebagai biaya. Pendapatan bersih tertinggi pada petani terdapat pada usahatani persawahan menggunakan peralatan tenaga kerja hewan kombinasi tenaga fisik manusia, atau menggunakan mesin traktor tangan. Sedangkan pada hutan rakyat tidak memerlukan biaya dalam pemanenannya, dikarenakan penjualan kayu pada hutan rakyat dilakukan secara pohon berdiri dengan harga Rp. 150.000 perpohon tanpa membedakan jenisnya pada pengusaha pemanen kayu menggunakan chainsaw. Pendapatan dari tegakan kemiri meskipun surplus, tetapi lebih rendah dibanding dengan persawahan dengan pengelolaan yang tidak intensif, hanya pada saat pemungutan buah kemiri, tegakan kemiri tersebut disiangi seadanya untuk memudahkan pemanenan buah kemiri. Hasil analisis tersebut menunjukkan besarnya daya tarik bagi petani untuk mengkonversi lahannya ke lahan persawahan, dikarenakan lebih tingginya penerimaan dan lebih rendahnya curahan tenaga kerja yang diperlukan dibanding wanatani lainnya (Tabel 6).

\section{Biaya dan pendapatan wanatani di Desa Timpuseng}

Hasil perhitungan biaya dan pendapatan wanatani (Tabel 7) menunjukkan usahatani persawahan di Desa Timpuseng juga memberikan pendapatan tertinggi dibanding penggunaan lahan lainnya. Pada wanatani ladang menetap, penerimaan petani surplus dengan memperhitungkan tenaga kerja keluarga sebagai biaya, dikarenakan curahan tenaga kerja berkurang pada kegiatan persiapan lahan. Persiapan lahan pada ladang menetap dengan rotasi rata-rata 5-7 tahun pembukaan lahannya lebih ringan dibanding dengan ladang berpindah, karena tegakan pohon yang ditebang belum besar dan belum banyak. Di samping intensitas perondaan dari babi hutan dan monyet juga lebih rendah dibanding ladang berpindah dengan penggunaan pagar hidup dari gamal dan masih terdapatnya pagar batu yang pernah dibangun pada rotasi sebelumnya. Penggemukan sapi di Desa Timpuseng dilakukan dikarenakan semakin terbatasnya lahan hutan dan padang rumput untuk penggembalaan ternak dilepas, dan adanya peraturan tentang pengendalian ternak untuk memprioritaskan budidaya tanaman dipersawahan

Table 6. Farmer Costs and Income on Several Agroforestry Pattern at Limampoccoe Village

\begin{tabular}{|l|c|c|c|c|c|c|c|}
\hline \multirow{2}{*}{$\begin{array}{c}\text { Cost items } \\
\text { (Rp/ha) }\end{array}$} & $\begin{array}{c}\text { Tegakan } \\
\text { kemiri }\end{array}$ & $\begin{array}{c}\text { Ladang } \\
\text { berpindah }\end{array}$ & $\begin{array}{c}\text { Hutan } \\
\text { rakyat }\end{array}$ & $\begin{array}{c}\text { Ternak } \\
\text { sapi semi } \\
\text { ekstensif }\end{array}$ & Aren & $\begin{array}{c}\text { Sawah } \\
\text { Mekanis } \\
\text { traktor }\end{array}$ & $\begin{array}{c}\text { Sawah t. kerja } \\
\text { manusia+ } \\
\text { hewan }\end{array}$ \\
\hline 1. Tenaga kerja & 31.000 & 2.670 .338 & -- & 2.160 .000 & 3.600 .000 & 441.643 & 1.680 .357 \\
\hline 2. Bibit & & 458.305 & -- & -- & -- & -- & -- \\
\hline 3. Mesin traktor & & -- & -- & -- & -- & 749.228 & -- \\
\hline 4. Saprodi & & -- & -- & -- & -- & 252.239 & 299.583 \\
\hline Total Biaya & & 3.128 .643 & -- & -- & 3.600 .000 & 1.443 .110 & 1.974 .940 \\
\hline Penerimaan & 248.656 & 2.696 .161 & 1.400 .000 & 3.500 .000 & 2.116 .500 & 7.755 .055 & 8.332 .571 \\
\hline Keuntungan & & -432.482 & 1.400 .000 & 1.340 .000 & -1.483 .500 & 6.311 .945 & 6.357 .631 \\
\hline Rerata luas lahan & & 1 & $0,4 \mathrm{Ha}$ & 2 ekor sapi & & 1 & 1 \\
\hline
\end{tabular}


Table 7. Farmer Costs and Income on Several Agroforestry Pattern at Timpuseng Village

\begin{tabular}{|c|c|c|c|c|c|c|c|}
\hline \multirow{2}{*}{$\begin{array}{c}\text { Cost items } \\
\text { (Rp/ha) }\end{array}$} & \multicolumn{7}{|c|}{ Costs of agroforestry patterns $(\mathrm{Rp} / \mathrm{Ha})$} \\
\hline & $\begin{array}{l}\text { Hutan } \\
\text { kemiri }\end{array}$ & Ladang & $\begin{array}{l}\text { Hutan } \\
\text { rakyat }\end{array}$ & $\begin{array}{c}\text { Ternak Sapi } \\
\text { intensif }\end{array}$ & $\begin{array}{c}\text { Kebun } \\
\text { campuran }\end{array}$ & $\begin{array}{c}\text { Sawah } \\
\text { (kacang) }\end{array}$ & $\begin{array}{l}\text { Sawah } \\
\text { (padi) }\end{array}$ \\
\hline $\begin{array}{l}\text { 1. Tenaga kerja mengolah } \\
\text { lahan sampai panen }\end{array}$ & -- & 1.676 .119 & -- & 1.360 .000 & -- & 1.189 .636 & 456.666 \\
\hline 2. Bibit & -- & 213.92 & -- & 4.000 .000 & -- & 601.494 & -- \\
\hline 3. Mesin traktor & -- & -- & -- & -- & -- & 751.869 & 754.486 \\
\hline 4. Saprodi & -- & -- & -- & -- & -- & -- & 254.010 \\
\hline Total biaya & -- & $1,890.048$ & -- & -- & -- & 2.542 .999 & 1.465 .162 \\
\hline Penerimaan & -- & 2.494 .862 & -- & 8.000 .000 & -- & 3.256 .766 & 8.727 .093 \\
\hline Pendapatan bersih & 604.814 & 604.814 & -- & -- & -- & 713.767 & 7.261 .931 \\
\hline Keterangan & -- & $\begin{array}{l}\text { Ladang } \\
\text { menetap }\end{array}$ & -- & $\begin{array}{l}\text { Penggemuk } \\
\text {-an sapi }\end{array}$ & -- & -- & -- \\
\hline Rerata luas lahan & -- & 1 & -- & -- & -- & -- & 0.754 \\
\hline
\end{tabular}

dan mengurangi biaya dan curahan tenaga kerja pemagaran. Pendapatan petani dari komoditas padi juga lebih tinggi dibanding dengan menanam komoditas kacang tanah.

Lebih menguntungkannya mengusahakan padi sebagai komoditas subsistensi pangan pokok sekaligus komoditas komersil, dan peluang berhasilnya lebih besar dikarenakan ketersediaan air pada musim hujan, serta mudahnya mengelola tanah persawahan dengan penggunaan mesin traktor tangan atau ternak kuda dibanding secara peralatan manual (parang, kampak, dan cangkul) yang membutuhkan tenaga fisik manusia yang lebih banyak pada ladang, merupakan salah satu faktor utama penduduk mengkonversi lahannya menjadi sawah.

\section{Biaya wanatani di Desa Batupute}

Hasil analisis biaya dan pendapatan petani wanatani di Desa Batupute (Tabel 8) menunjukkan wanatani pekarangan dominan coklat memberikan pendapatan tertinggi dibanding pada sawah tadah hujan yang terdapat pada desa bersangkutan yang hanya dapat ditanami tanaman musiman (terutama padi atau jagung pada musim hujan).

Lebih besarnya pendapatan yang dapat diperoleh dari pola wanatani berbentuk pekarangan, kebun campuran dan ladang menetap dibanding hutan kemiri monokultur dan hutan jati, menyebabkan banyak lahan penduduk yang mengkonversi hutan kemiri dan hutan jatinya menjadi wanatani pekarangan, atau kebun campuran dengan terlebih dahulu melalui proses berladang secara bero.

Konversi menjadi sawah tidak banyak dilakukan dikarenakan faktor pembatas iklim wilayah yang hanya 3-4 bulan musim kerjanya dan tidak tersedianya pengairan non teknis atau sungai besar untuk sumber air secara pompanisasi. Biaya yang timbul dari berbagai pola wanatani di desa bersangkutan sebagian besar biaya tenaga kerja keluarga yang dinilai $R p$ 15.000 per hari, dikarenakan masih menggunakan peralatan manual, kecuali pada persawahan yang sudah menggunakan traktor tangan.

Table 8. Farmer Costs and Income on Several Agroforestry Pattern at Batupute Village

\begin{tabular}{|c|c|c|c|c|c|c|}
\hline \multirow[b]{2}{*}{ Cost items (Rp/ha) } & \multicolumn{6}{|c|}{ Costs of agroforestry pattern $(\mathrm{Rp} / \mathrm{Ha})$} \\
\hline & $\begin{array}{l}\text { Hutan } \\
\text { kemiri }\end{array}$ & $\begin{array}{l}\text { Ladang } \\
\text { menetap }\end{array}$ & $\begin{array}{c}\text { Kebun } \\
\text { campuran }\end{array}$ & $\begin{array}{c}\text { Ternak Sapi } \\
\text { ekstensif }\end{array}$ & Pekarangan & $\begin{array}{l}\text { Sawah } \\
\text { (padi) }\end{array}$ \\
\hline $\begin{array}{l}\text { 1. Tenaga kerja mengolah } \\
\text { lahan sampai panen }\end{array}$ & 140.668 & 2.025 .000 & 1.692 .973 & 2.160 .000 & 234.375 & 393.511 \\
\hline 2. Bibit & -- & 350.000 & -- & -- & -- & 300.000 \\
\hline 3. Saprodi & -- & -- & -- & -- & 234.375 & 252500 \\
\hline 4. Mesin traktor & -- & -- & -- & -- & -- & 524.681 \\
\hline Total biaya & -- & 2.375 .000 & 1.692 .973 & -- & 1.905 .804 & 1.470 .692 \\
\hline Penerimaan & 937.790 & 4.703 .099 & 4.218 .641 & 3.500 .000 & 4.535 .714 & 4.328 .617 \\
\hline Pendapatan bersih & 797.112 & 2.328 .099 & -- & 1.340 .000 & 7.887 .053 & 2.857 .925 \\
\hline Rata-rata luas lahan & 1.96 & 1.73 & 1.1 & $\begin{array}{r}1 \text { ekor sapi } \\
\text { dewasa } \\
\end{array}$ & 0.64 & 0.8 \\
\hline
\end{tabular}


Table 9. Matrix of Farmer Income Levels on Upperstream Minraleng Sub Watershed

\begin{tabular}{|c|c|c|c|c|c|c|c|c|c|c|c|c|c|}
\hline \multirow{2}{*}{$\begin{array}{l}\text { Income } \\
\text { resources }\end{array}$} & \multicolumn{12}{|c|}{ Months } & \multirow{2}{*}{$\begin{array}{c}\text { Income } \\
\text { levels }\end{array}$} \\
\hline & Jan & Feb & Mar & Apr & Mei & Jun & Jul & Ags & Sep & Okt & Nov & Des & \\
\hline Kemiri & & & & & & & & & & & & & $\mathrm{V}$ \\
\hline Coklat & & & & & & & & & & & & & II \\
\hline K. tanah & & & & & & & & & & & & & III \\
\hline Jagung & & & & & & & & & & & & & IV \\
\hline Padi & & & & & & & & & & & & & $\mathrm{I}$ \\
\hline Ternak sapi & & & & & & & & & & & & & III \\
\hline Kayu Jati & & & & & & & & & & & & & III \\
\hline Jahe & & & & & & & & & & & & & IV \\
\hline
\end{tabular}

Matriks peringkat pendapatan petani di Sub DAS Minraleng Hulu diperlihatkan pada Tabel 9, yang didasarkan pada hasil analisis biaya dan pendapatan pada ketiga lokasi penelitian.

\section{KESIMPULAN DAN SARAN}

1. Indeks keanekaragaman tanaman usaha wanatani hutan rakyat campuran lebih tinggi dibandingkan pola usaha wanatani lainnya, sedangkan rata-rata indeks keanekaragaman terendah terdapat pada pola usaha wanatani ladang

2. Pola usaha wanatani kebun campuran mempunyai tingkat pendapatan yang tinggi dibanding usaha wanatani lainnya, meskipun lebih rendah kontribusinya dibanding pada usahatani persawahan.

3. Pola usahatani sawah dan usaha wanatani ladang mempunyai kontribusi pendapatan tinggi bagi petani, tetapi tingkat keanekaragaman jenis tanamannya rendah, sedang untuk usaha wanatani kemiri monokultur dan kebun campuran mempunyai keanekaragaman jenis tanaman yang tinggi dengan kotribusi pendapatan yang rendah.

4. Perlu diversifikasi pemanfaatan ruang tumbuh dibawah tegakan kemiri monokultur dan intensifikasi tanaman bernilai ekonomis pada usaha wanatani kebun campuran yang dapat meningkatkan memberikan kontribusi pendapatan petani dan meningkatkan keanekaragaman jenis tanaman yang bersifat ekonomis dan ekonomis pada lahan petani.

Diterima : 25 Juni 2007

\section{Muhammad Dassir}

Lab. Pemanenan dan Pembukaan Wilayah Hutan

Kampus Unhas, Jl. P. Kemerdekaan Km. 10 Tamalanrea Telp/Fax. (0411) 589592. Indonesia

\section{DAFTAR PUSTAKA}

Cohran, G.W. 1977. Sampling Techniques. Penerbit John Wiley and Sons. New York.

Foresta, H.D., A. Kusworo, G. Michon dan W.A. Djatmiko. 2000. Ketika Kebun Berupa Hutan: Agroforest Khas Indonesia. Sebuah Sumbangan Masyarakat. Penerbit SWMT Grafika Desa Putera. Jakarta.

Gintings. 1997. Pengelolaan Sumberdaya Lahan Kering di Indonesia. Penerbit APAN. Bogor.

Jamal, E. 2000. Beberapa Permasalahan Dalam Pelaksanaan Reformasi Agraria di Indonesia. Forum Penelitian Agroekonomi (FAE) Vol. 18 No.1-2. Pusat Penelitian Sosial Ekonomi. Badan Penelitian dan Pengembangan Pertanian, Departemen Pertanian. Bogor.

Millang, S. 2003. Master Plan Study on Integrated Development and Management of the Walanae-Cenranae River Basin. Departemen Pemukiman dan Infrastruktur Wilayah Republik Indonesia, Direktorat Umum Sumberdaya Air (Tidak Dipublikaskan).

Reijntjes, C.B., B. Haverkont dan A.W. Bayer. 1992. Farming for the Future: an Introduction to Low-External-Impact and Sustainable Agriculture. Alih Bahasa: Y. Sukoco. Kanisius. Jakarta.

Ruf, F. dan F. Lancon. 2005. Dari Sistem Tebas dan Bakar Ke Peremajaan Kembali. Penerbit Salemba Empat. Jakarta. 